\title{
Effect of cylinder power and axis changes on vision in astigmatic participants: a comment [Letter]
}

This article was published in the following Dove Press journal: Clinical Optometry

Laura Remón'

Walter D Furlan ${ }^{2}$

'Departamento de Física Aplicada, Universidad de Zaragoza, 50009 Zaragoza, Spain; ${ }^{2}$ Departamento de Óptica y Optometría y Ciencias de la Visión, Universitat de València, 46100 Burjassot, Spain
Correspondence: Laura Remón Departamento de Física Aplicada, Facultad de Ciencias, Universidad de Zaragoza, C/ Pedro Cerbuna, I2, Zaragoza 50009, Spain

Email lauremar@unizar.es

\section{Dear editor}

We read with interest the article by Sha et $\mathrm{al}^{1}$ in the March 2019 issue. This study evaluated the effects of misalignment axis and undercorrecting cylinder powers on the visual performance of astigmatic people. The aim of this work was mainly to assist eye-care practitioners in reducing the number of toric contact lenses stock-keeping units. The authors analyze the effect of astigmatic undercorrection by $0.25,0.50$ and $0.75 \mathrm{DC}$, at different amounts of misalignments up to $30^{\circ}$. In this analysis, the effects of cylinder power, cylinder axis and their mutual interaction are analyzed separately. However, it is well known that cylinder power and axis are not independent variables; in fact, astigmatism is a vector magnitude. Several studies ${ }^{2,4}$ use vector formalism to quantify the blur strength produced by astigmatism. Even in previous literature, ${ }^{1}$ the authors show the power vector components $\left(M, J_{0}, J_{45}\right)$ in Table 1, for the different groups in which the sample is divided. However, unexpectedly, they do not use the same formalism to analyze the data (see Tables 2, 3 and Figures 2-6). In this sense, in our opinion, it would have been much useful to show the results for the evaluated visual parameters in terms of a single scalar variable such as the blur strength $\left(B=\sqrt{\left(M^{2}+J_{0}^{2}+J_{45}^{2}\right)}\right)$. This could have been done by computing the modulus of the vector difference between the full correction and the different simulated miscorrections, and then representing the different parameters of interest (HCVA, LCVA, etc.) vs the blur strength. In this way, the rate of change of each parameter per unit blur strength could have been computed. ${ }^{2}$ From the data in reference [1] (Figure 2 and Table 1), corresponding to high cylinder group HCVA, we found that the fit very well with the expression: $\operatorname{logMAR}=0.37 \mathrm{~B}-0.1$ which is the empirical equation that we found previously, ${ }^{3}$ which is also mentioned in reference [2].

Finally, it is important to note that, like happens for the HCVA, ${ }^{4}$ the rate of change of the other visual parameters with the blur strength may depend on the type of residual astigmatism, and also on the amplitude of accommodation of the participants. This may be one of the reasons for the different slopes in the data corresponding to undercorrection by $0.75 \mathrm{DC}$ in the above-mentioned Figure 2 (dotted line). 
In conclusion, by using the vector power formalism, practitioners could obtain the answer to the following question: Which is the maximum tolerable difference in the amount of blur strength $(B)$ between 2 lenses in my stock? This result would certainly be useful to "assist in determining opportunities for reducing stock-keeping units of toric contact lens".

\section{Disclosure}

The authors report no conflicts of interest in this communication.

\section{References}

1. Sha J, Fedtke C, Tilia D, et al. Effect of cylinder power and axis changes on vision in astigmatic participants. Clin Optom. 2019;11:27-38. doi:10.2147/OPTO.S190120

2. Atchison DA, Mathur A. Visual acuity with astigmatic blur. Optom Vis Sci. 2011;88(7):E798-E805. doi:10.1097/OPX.0b013e31821 98792

3. Remón L, Tornel M, Furlan WD. Visual acuity in simple myopic astigmatism: influence of cylinder axis. Optom Vis Sci. 2006;83 (5):311-315. doi:10.1097/01.opx.0000197958.83213.b1

4. Remón L, Monsoriu JA, Furlan WD. Influence of different types of astigmatism on visual acuity. $J$ Optom. 2017;10(3):141-148. doi:10.1016/j.optom.2016.07.003

Dove Medical Press encourages responsible, free and frank academic debate. The content of the Clinical Optometry 'letters to the editor' section does not necessarily represent the views of Dove Medical Press, its officers, agents, employees, related entities or the Clinical Optometry editors. While all reasonable steps have been taken to confirm the content of each letter, Dove Medical Press accepts no liability in respect of the content of any letter, nor is it responsible for the content and accuracy of any letter to the editor.

\section{Clinical Optometry}

\section{Publish your work in this journal}

Clinical Optometry is an international, peer-reviewed, open access journal publishing original research, basic science, clinical and epidemiological studies, reviews and evaluations on clinical optometry. All aspects of patient care are addressed within the journal as well as the practice of optometry including economic and business analyses. Basic and clinical research papers are published that cover

Submit your manuscript here: https://www.dovepress.com/clinical-optometry-journal all aspects of optics, refraction and its application to the theory and practice of optometry. The manuscript management system is completely online and includes a very quick and fair peer-review system, which is all easy to use. Visit http://www.dovepress.com/ testimonials.php to read real quotes from published authors. 